\title{
How Chinese commercial banks innovate: process and practice
}

\author{
Kok Lian, WOO \\ Faculty of Economic and Management Sciences, Université Paris-Dauphine, Dauphine \\ Doctoral School, Paris, France \\ Woo_Kok_Lian@hotmail.com
}

\begin{abstract}
This paper describes the financial innovation approach and process adopted by large commercial banks operating in China. Data are collected from three case firms using a qualitative case study method. The research shows that regulation can be a catalyst or a hindrance to financial innovation, depending upon the degree of coherence between a bank's innovation strategy and local government policy. Performance pressure helps drive innovation, whereas organisational bureaucracy and trajectory are major barriers to innovation. Banks adopt different approaches to the innovation process due to differences in institutional arrangement and institutional environment. Practitioners should consider the institutional effects when engaging in financial innovation. This research contributes to current practice by pointing out an integrated approach to financial innovation and regulatory dialectic.
\end{abstract}

Keywords. Innovation Process, Innovation Model, Regulatory Dialectic Financial Services

\section{Introduction}

Financial services represented $10 \%$ of China's gross domestic product (GDP) in 2014, growing by $17 \%$ annually. Innovation in financial services is undergoing a massive change in China with the rise of the mobile Internet, cloud computing and the Internetplus economy (based on the study of Lee and Yang (2014), it is similar to Industry 4.0 in the Western literature). Large IT firms such as Alibaba, Baidu and Tencent have penetrated the financial services industry through third-party online payment platforms and have begun to provide branchless banking services. They have started to disrupt the traditional ways in which financial services are provided by using an agile service model and offering an enriched customer service experience. These in-pocket banking services are available to users anywhere, anytime, 24x7. Financial innovation by outsiders helps drive creativity and big data analytics on customer spending behaviour. Some banks have started to work with IT firms to deliver new banking services to consumers over the mobile Internet.

However, these new forms of financial innovation have also had an unexpected impact on financial stability. Standard \& Poor (S\&P) estimates that, as of the end of 2014, shadow banking in China totalled RMB 25 trillion and provincial government had accumulated debt of RMB 115 trillion, 55\% and 250\% of China's GDP respectively. The Financial Stability Board (FSB, 2011) defines shadow banking broadly as "credit intermediation involving entities and activities outside the regular banking system". 
These unregulated financial activities create credit and liquidity risks in the Chinese financial system, as a result of over-leveraging and a rapid increase in lending activity. Shadow banking in China will continue to grow as long as commercial bank lending is unable to meet the liquidity demands of business and interest expectations for investment.

Some of this debt has been created as a result of the booming Internet finance (according to Schueffel (2017), it is equivalent to the term "FinTech" using in the Western literature) economy and limited investment channels in China. Internet finance refers to financial activities driven by IT firms leveraging the innovative power of Internet technology. It is a new form of economy driving consumption and microfinancing in China. Internet finance is easily accessible by low-income individuals for immediate financing, without any mortgaging or comprehensive credit rating. It also offers high-interest wealth management products over the Internet to individuals without any appropriate risk tolerance checks.

The increase in shadow banking and under-regulated Internet finance activities is due to the reluctance of commercial banks to supply credit to small and medium enterprises (SMEs), despite the fact that Chinese SMEs account for approximately $60 \%$ of GDP and supply more than $75 \%$ of jobs in China. With the marketisation of interest rates and the further opening up of the banking industry to foreign investment, Chinese banks will need to be more innovative in their operations, products and services provision in order to remain competitive. However, exactly how Chinese banks innovate remains a neglected research area in most innovation studies.

This paper studies the innovation process and approach adopted by large commercial banks in the context of their institutional arrangement and the Chinese financial institutional environment. Process can be defined as a set of activity flows that take place within relatively stable contexts, such as the organisation or the institutional environment. This exploratory research also reviews the implications of regulatory environment on a bank's innovation model. Three large commercial banks in China, with different equity ownership, innovation strategies and organisational trajectories, were selected for case study. The paper ends with a cross-case analysis and a discussion of managerial and policy implications.

\section{$2 \quad$ Literature review}

\subsection{What is innovation?}

There is no uniform definition of innovation. In general, innovation is associated with original, never-before-seen products or the use of cutting-edge technologies. Innovation can be the development and commercialisation of new products or services (Rogers, 2003); the development of new manufacturing processes or forms of service provider relationship (OECD, 2005); drastically different concepts or completely new ways of setting apart existing business (Hamel, 2000); changing a company's organisational and management style and the administration of the production process (Van de Ven, Angle \& Poole, 2000); or ways of commercialising new products, new delivery methods and changes in packaging (Jaramillo, Lugones \& Salazar, 2000). 
Innovation can be defined based on four schools of thought:

(1) The classic definition: "a historic and irreversible change in the method of production of things" and "creative destruction" (Schumpeter, 1934);

(2) The OECD definition: "the implementation of a new or significantly improved product (good or service), or process, a new marketing method, or a new organisational method in business practices, workplace organisation or external relations" (OECD, 2005, p.46);

(3) The theory of change definition: innovation as something new (Barnett, 1953); a conduit of change (Drucker, 1985; O'Sullivan \& Dooley, 2009); a process (Aiken \& Hage, 1971; Rasul, 2003); a value driver (Wang \& Kafouros, 2009); or an invention (Zaltman, Duncan \& Holbek, 1973);

(4) The competitive advantage definition: "a source of competitive advantage and is seen as a decisive factor for economic growth and the basic condition of company development in a competitive environment" (Johannessen, 2009); or "a tool for the creation of new knowledge. The use of new products, services, processes and paradigms that are embedded into existing innovation leads to new ways of thinking and new knowledge" (Acs, Anselin \& Varga, 2002; Strambach, 2002).

Other contemporary descriptions of innovation, to name just a few, include "blue ocean innovation" (Kim \& Mauborgne, 2005); "frugal innovation" (Tiwari \& Herstatt, 2011); "organic innovation" (Moore, 2005); and "open innovation" (Chesbrough, 2006). In this paper, the author prefers to define innovation as a conduit of change and creator of values (Poole, 2004). Innovation is always followed by change, but the change does not necessarily result from innovation. Change can be a result of objectives being compromised, or of regulation compliance (Van de Ven \& Poole, 1995). Innovation nowadays not only means the creation of something new; it is also a panacea for survival and growth. Innovation is required to continue to enhance the value proposition of a business. The innovation concept has changed - from the invention of new things, to value creation and being a change agent. Innovation is seen as market conquest and a profit driver in business today.

\subsection{What is financial innovation?}

Lerner and Tufano (2011, p.6) define financial innovation as "the act of creating and then popularising new financial instruments, as well as new financial technologies, institutions and markets. The innovations are sometimes divided into product or process variants, with product innovations exemplified by new derivative contracts, new corporate securities or new forms of pooled investment products, and process improvements typified by new means of distributing securities, processing transactions or pricing transactions."

Products of financial innovation in the early 2010s were financial instruments such as ETFs (exchange-traded funds), hybrid complex MTNs (medium-term notes), sovereign CDS (credit default swaps on sovereign debt) and liquidity swaps, and new trading practices such as HFT (high-frequency trading) (Muniesa and Lenglet, 2013). Frame and White $(2004$, p.118) further conclude that financial innovations may embrace "new products (e.g. adjustable-rate mortgages, exchange-traded index funds), new services (e.g. Internet banking, online securities trading), new production processes (e.g. credit 
scoring models, electronic record-keeping for securities) or new organisational forms (e.g. new types of electronic exchange for trading securities, Internet-only banks)".

Most literature considers financial innovation to be an organisational process (Cooper, 1998; Oke \& Goffin, 2001) which includes idea generation, concept evaluation, development and commercialisation (Luecke, 2003; Vermeulen, 2004). The innovation process can be episodic or continuous (Weick \& Quinn, 1999), first-order or secondorder (Meyer et al, 1993) and competence-enhancing or competence-destroying (Abernathy \& Clark, 1985). Rothwell (1994) defines innovation development in six generations: technology push, market pull, coupling, interactive, network, open innovation.

Financial innovation takes many forms. It can be incremental or radical (Tushman \& Romanelli, 1985), sustaining or disruptive (Christensen et al, 2003). Atherton and Hannon (2000) consider business strategy to be the building block and antecedent to all kinds of innovation. From a practitioner view, financial innovations include ICTbased innovation (Lichtenthaler, 2007), product innovation (Vermeulen, 2004), service innovation (Kutvonen et al, 2011), process and platform innovation (Coles \& Edelman, 2012), channel innovation (Prahalad \& Krishna, 2008), integration innovation (Ward \& Daniel, 2012) and open innovation (Chesbrough, 2006).

Llewellyn (1992) identifies three fundamental differences between financial innovation and innovation in other sectors: (1) unlike in many industries, the R\&D costs of creating new products are relatively low in the financial sector; (2) due to lack of invention patent protection, financial innovation is easy to copy; and (3) financial innovation is strongly influenced by regulation - it often derives from the desire to elude legal stipulations or exploit regulatory gaps or grey areas. The fact that financial innovation is visible and immediately copied contributes to increasing financial integration at an international level (p.16).

Four distinctive features of financial innovation have been emphasised in the literature. First, the role of regulation either as an innovation catalyst or as a hindrance factor has been widely debated (Marcus, 1981). Second, until recently most financial innovations were not considered eligible for patent protection (Kumar \& Turnbull, 2006; Lerner, 2006). Third is the propensity of innovation activities to entail cooperation. Vence and Trigo (2009) find strong evidence of inter-firm cooperation, whereas Oliveira and Von Hippel (2011) highlight the importance of users as co-creators in the retail banking industry. Fourth, innovation in financial services is usually depicted as incremental. Weak appropriability regimes and ease of imitation, combined with a resourceintensive, time-consuming and costly innovation process, hinder the development of radically new offerings (Easingwood, 1986; de Brentani, 2001; Alam, 2002).

\subsection{Characteristics of financial innovation}

A positive relationship has been found between networking, open innovation and business performance. Banks can achieve higher revenue growth by participating in networks and engaging in open innovation (Chaston, 2011). Involving customers in the open innovation process can enhance innovation quality and outcome. Stakeholder integration and the involvement of supporting activities units (Akamavi, 2005), and engaged communication with lead customers (Athanassopoulou \& Johne, 2004) and 
project team members (Lievens \& Moenaert, 2001), are important to the success of financial innovation. However, Costanzo and Ashton (2006) find the innovation process to be more market-oriented than customer-oriented, and thus most banks adopt a strategy of targeting the quick launch of slightly modified offerings as a response to competition, rather than truly identifying and meeting customer needs. Direct involvement of customers appears extremely rare, which may be explained by the degree of inherent complexity of financial innovation and the lack of customer interest in these innovations (Vermeulen, 2004, p.94). Using a co-creation and co-profiting approach, Martovoy et al (2014) suggest that financial institutions should select customers who are more demanding and with whom it is possible to cooperate (in retail markets), and customers with whom they have longstanding and intertwined relationships (in corporate markets). Instead of searching for innovation best practices, Bátiz-Lazo and Woldesenbet (2006) suggest that multiple adoption patterns could be possible in banking.

In terms of the pattern of financial innovation development, Martovoy and Mention (2016) identify four patterns of new service development (NSD) processes: problemdriven, proactivity-driven, market-driven and strategy-driven. Most banks are found to keep a balance between being open and closed to cooperation with external partners in the innovation process. In general, service concept development is the innovation stage most open to cooperation, while introduction to a market is more in-house oriented.

Romelaer (2015) classifies innovation (also applicable to financial innovation) in five major models: rational, behavioural, technocratic linear, concurrent with outsider help, and progressive with intrapreneur models. Each model is different in terms of innovation actors, activities and communication types. The model moves from a supposedly 'rational' model to a more realistic and practical model. It shows an increasing use of initiative, bottom-up processes, decentralisation, co-development, shared governance and use of outside resources.

Numerous scholars have studied factors affecting financial innovation process, efficiency and performance. These factors include organisational structure (Berger \& Udell, 2002); organisational culture (Vermeulen, 2004); human resources (Glaveli \& Kufidu, 2005); top management support and customer focus (Gerstlberger et al, 2010); information and communications technology (ICT) (Berger, 2003); legal environment (Jawahitha et al, 2003); communication flow (Lievens \& Moenaert, 2000a); competition (Bradley \& Stewart, 2003a, b); and cost (Gurau, 2002). Different means such as patents (Lerner, 2006), technology embeddedness (Frame \& White, 2004) and user stickiness (Rigby \& Zook, 2002) are used to protect the proprietary nature of financial novelties. Financial innovation activities are usually measured by investment in information technology (Beccalli, 2007), new product rate (Sumita, 2008) and research and development (R\&D) expenditure (Adams et al, 2006). The use of ICT is also considered a relevant prerequisite for financial innovation, because of the high volume, variety and velocity of financial transactions that need proper recording to safeguard financial asset ownership (Gerstlberger et al, 2010).

\subsection{Current literature gaps}

Current literature shows limited understanding of how financial innovation is being managed and why banks manage the innovation process in the way they do. This is due 
to the general reluctance of banks to reveal their innovation decision-making process.

Access to data is difficult due to regulatory restrictions and business confidentiality. Financial service firms rarely report R\&D spending, and financial patents were used only infrequently until recently (Lerner and Tufano, 2011). Lerner (2006) takes a new approach in addressing this gap by developing a measure of financial innovation based on news and stories in the Wall Street Journal. He finds firms that are less profitable in their sector are disproportionately more innovative. These results are consistent with Silber (1983), who says that more marginal firms contribute the bulk of the innovations in the financial services sector. However, this is in contrast to the last decade, during which most new financial innovations were initiated by large financial institutions with the advantage of market size in product diffusion and transfer of risk.

The innovation process proliferates into complex bundles of innovation ideas and divergent paths of activities by different organisational units (Van de Ven \& Poole, 1995). Blazevica and Lievensb (2004) suggest future research should consider case studies that provide more insight into the different stages of innovation and its interaction with the communication necessary to ensure innovation success and competence development. Lerner and Tufano (2011) further suggest that comparative case studies can offer additional evidence to help uncover the innovation spiral process. By judicious selection of case banks of systemic importance to the Chinese financial system, the researcher can "walk the path" (Calori, 2003) of the innovation process in practice, and identify gaps between "espoused theory" and "theory in use" (Argyris \& Schon, 1978).

Romelaer (2015) suggests that innovation study should consider a better understanding of formal-informal-cultural aspects of the innovation; how innovation links to strategy, internal and external constraints and resources; and inside and outside governance in relation to types of project managers, owners and investors, district, regional or state influences. The organisational type may also have a strong influence on the innovation model applied. However, it is unclear to us why certain innovation models are more common in certain national or regional cultures (Asia and China), in certain industries (such as financial services), and in certain types of firm (foreign, state-owned and privately owned). Can all types of innovation process be gathered in a single framework? What are the specific advantages, disadvantages and managerial concerns of each model? An empirical study that is based on direct observation or experiences in the field might be able to unearth these mysteries.

\section{Research methods}

Process study is increasingly popular in the study of organisational change and innovation. It focuses on how change unfolds by narrating the temporal sequence of events in an organisational setting (Poole et al, 2000). In empirical research, process study employs clinical designs to identify the process or multi-concurrent processes through direct observation, archival analysis or multiple case studies (Van de Ven \& Poole, 2005), but a process study's generalisability depends on its case study's versatility - "the degree to which it can encompass a broad domain of developmental patterns without modification of its essential character" (Poole et al, 2000, p.43). 
To gain practical insight into the financial innovation process, we need information from experienced managers involved in the end-to-end innovation process. Three research activities were conducted (see Table 1): an exploratory study, case studies and a pragmatic study. A total of 30 informants were interviewed several times between 2013 and 2015.

Table 1. An overview of empirical research activities (2013-2015)

\begin{tabular}{lll}
\hline $\begin{array}{l}\text { Research } \\
\text { activity }\end{array}$ & Goal & Research instrument \\
\hline $\begin{array}{l}\text { Exploratory } \\
\text { research }\end{array}$ & $\begin{array}{l}\text { Preliminary data collection } \\
\text { and concept review }\end{array}$ & $\begin{array}{l}\text { Executive interviews and field } \\
\text { observations }\end{array}$ \\
\hline Case studies & $\begin{array}{l}\text { Empirical study data } \\
\text { collection and analysis }\end{array}$ & $\begin{array}{l}\text { Executive interviews, workshop } \\
\text { discussions, field observations and } \\
\text { written documents review }\end{array}$ \\
\hline $\begin{array}{l}\text { Pragmatic } \\
\text { study }\end{array}$ & $\begin{array}{l}\text { Identification of gaps } \\
\text { between espoused theory } \\
\text { and theory in use }\end{array}$ & $\begin{array}{l}\text { Executive interviews, field } \\
\text { observations and internal documents } \\
\text { review }\end{array}$ \\
\hline
\end{tabular}

First, an exploratory study was conducted to collect preliminary data from the field about the research subject and practitioners' voices. The key goal was to understand the research fieldwork environment, people, main themes and key concerns. The exploratory study was conducted in a pilot case firm, based on semi-structured and open-ended interviews. All interviews followed a common protocol. Informants were first asked to describe the innovation process, and subsequently more specific issues about innovation drivers, barriers, measurements, learning and development were discussed.

The empirical study was conducted based on an extended case study approach (Burawoy, 1991), using a theoretical sampling method (Eisenhardt, 1989). Three case firms were selected, based on a maximum difference approach (see Table 2). The idea is that greater variation in case firms leads to a higher chance of discovering similarities and dissimilarities among case firms for potential literal and theoretical replications (Yin, 2009). Under an embedded case study approach, all the case firms have significant operations in China and are subject to the regulatory governance of the China Banking Regulatory Commission (CBRC) and the People's Bank of China (PBOC). This exploratory case study attempts to answer the research questions "What is the innovation process?" and "How is innovation being managed?" in the Chinese banking industry. This study does not aim to describe propositions, test hypotheses or attempt to develop causal explanations in a real-life context.

Table 2. An overview of case study firms

\begin{tabular}{llll}
\hline & H BANK & C BANK & P BANK \\
\hline Ownership & Foreign bank & State-owned bank & Joint stock bank \\
\hline Headquarters (HQ) & Outside China & China & China \\
\hline Total assets & USD 2.5 trillion & USD 2.5 trillion & USD 0.35 trillion \\
\hline
\end{tabular}




\begin{tabular}{llll}
\hline & H BANK & C BANK & P BANK \\
\hline Years of operation & 150 & 60 & 60 \\
\hline Branches in China & 150 & 14 & 550 \\
\hline Core business & $\begin{array}{l}\text { International and } \\
\text { private banking }\end{array}$ & $\begin{array}{l}\text { Traditional deposit } \\
\text { and lending }\end{array}$ & $\begin{array}{l}\text { Banking, insurance } \\
\text { and investment }\end{array}$ \\
\hline Core competency & $\begin{array}{l}\text { Global business } \\
\text { network }\end{array}$ & $\begin{array}{l}\text { Connection with } \\
\text { policy-makers }\end{array}$ & $\begin{array}{l}\text { Comprehensive } \\
\text { financial service } \\
\text { offering }\end{array}$ \\
\hline
\end{tabular}

Finally, end users' opinions were collected to evaluate the innovation quality and performance of the case firms. Additional interviews were conducted at D FIRM to collect the user experience with the case banks' innovation products and innovation deployment process. Under this approach, the researcher and actors were engaged in a process of communicative action in the real life world, in order to reach an understanding by "walking the path' together and trying to reach a mutual understanding. This additional study helps identify gaps between "espoused theory" and "theory in use" (Argyris \& Schon, 1978). Based on the pragmatic study approach (Calori, 2002), the various theoretical concepts are used to capture the lived experience of innovation activities at the selected firms.

To ensure the collection of high-quality, reliable data from interviews, interviewees were selected based on the notion of 'key informants' who are the subject matter experts in the innovation process. These informants included organisational actors from different hierarchical levels, functional areas, groups and locations involved in the innovation process. Interviews began with semi-structured questions and switched to a conversational manner towards the end. An informal approach allowed the researcher to explore new themes and compare empirical data from different sources. The aim was to seek elucidation and elaboration from various participants, to reveal many-faceted themes and dimensions of financial innovation in a real-case experience. The interview transcripts were mainly recorded verbatim to preserve the raw data (Patton, 1990).

Within-case and cross-case studies were conducted to analyse the empirical data collected. Viewpoints were themed and grouped to look for patterns of similarities and contrasts, as well as uniqueness, rarity and disruption. As the interviews progressed, the analysis became more systematic and structured. Empirical data were organised and grouped to represent similarities and differences. Based on the grouping, key concepts were distinguished, categorised and integrated to find new themes and interesting patterns. Finally, storylines were developed as analytic threads to unite and integrate the major themes of the study. 


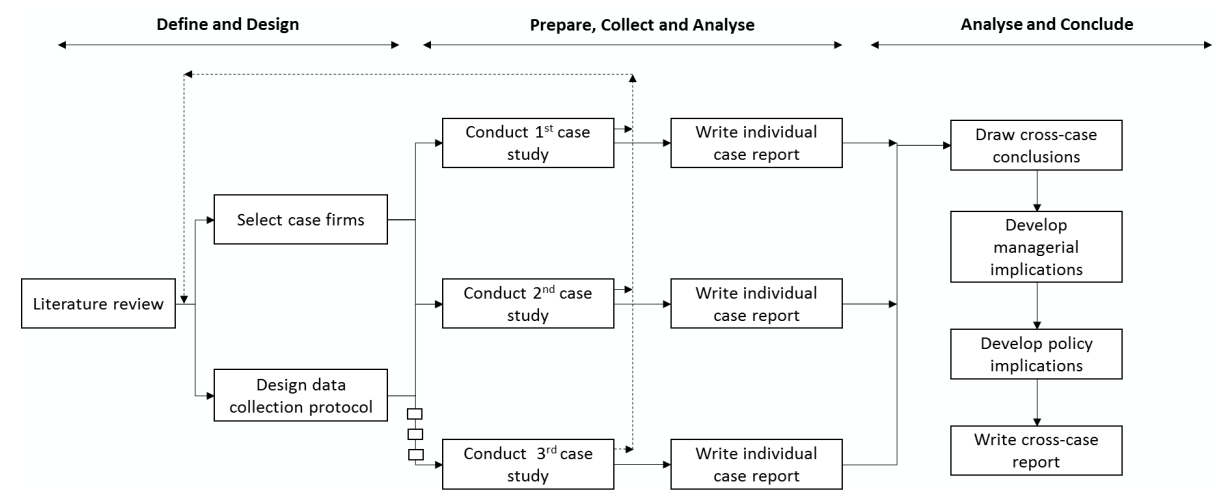

Fig. 1. The research approach and process

In the next section, three case studies on the innovation process of Chinese commercial banks are presented. Each case study begins with an illustration of the regulatory environment and business challenges facing the case bank in China. The innovation actors, key activities and processes are then analysed to present a holistic view of the innovation model adopted by the case bank.

\section{$4 \quad$ Empirical studies}

\subsection{Case Study 1: H BANK's actor network model}

China needs to open its banking sector to foreign competition in line with its commitment to the World Trade Organisation (WTO). As of December 2012, there were 42 China-incorporated foreign banks, 95 foreign bank branches and several hundred foreign bank representative offices in China, with total assets in 2012 of RMB 2.3 trillion. Some foreign banks made strategic minority investments in state-owned banks when these banks were privatised. Most foreign banks had support from the parent bank in the home country to help foster innovation, risk governance and a relationship with local authorities.

Although foreign banks have become familiar with navigating the Chinese market, they still face critical challenges.

- Regulation: excessive and complicated financial rules and regulations, limited access to the bond market and imposed constraints on capital and liquidity requirements.

- Operation: human resource issues, a complex legal environment, high operating costs and low profitability.

- Market growth: interest rate margin compression, the loss of retail customers and increasing competition from domestic banks.

Despite these challenges, the internationalisation of the Renminbi, interest rate liberalisation and relaxed regulations in free trade zones have given foreign banks new hope. To seize these opportunities, foreign banks need to establish an innovation process that can adapt to the Chinese regulatory environment yet comply with their 
global innovation policies and standards. "Regulation reformation is key to promoting financial innovation and diffusion. The Shanghai Free Trade Zone (SFTZ), for example, provides us opportunities to venture into new customer bases and supply chain financing needs. We successfully migrate mature financial products from other markets to meet the surging demand in the SFTZ," said H BANK's product manager.

Branches of international banks prefer to use the knowledge and experience possessed by other affiliates belonging to the identical corporate group (Martovoy \& Dos Santos, 2012; Martovoy et al, 2012). By doing so, these firms only adapt services to local needs - services which were otherwise developed in a different context and without the involvement of clients (Schueffel and Vadana, 2015). H BANK manages innovation activities on a global scale, actively using international talent teams in response to local innovation needs. Having global innovation capability and local participation in the innovation activities helps ensure business process standardisation and international practice harmonisation. However, this arrangement prevents $\mathrm{H}$ BANK from responding quickly to volatile market conditions and changes in local monetary policy.

The empirical study shows that H BANK has adopted a global-driven innovation strategy and process. New products need to align with global product standard and the business strategy. H BANK does not promote local product development, unless there are compelling legal and market outlook reasons. Local government can significantly influence foreign banks' decisions on product innovation. "In financial service sectors, the innovation decision is quite often affected by the relationship with the local government," said the business risk manager. Lu (2008) finds an interactive commitment between the Chinese government and H BANK, and this commitment relationship reduces $\mathrm{H}$ BANK's transaction costs by limiting the possibilities for government opportunism.

Two types of innovation communications were observed at H BANK. In global-local communication, the global team conducts a cross-market review of new development ideas, product concepts, specifications, risk controls, testing and deployment details with the local team within each business function. In local-local communication, the local team conducts domestic cross-functional coordination activities in the innovation deployment process, from domestic legal review and knowledge transfer to innovation diffusion. Although both forms of communication improve innovation engagement and diffusion across locations and business functions, having both increases the development cycle time and time-to-market. "Over-communication can be a constraint to innovation in a large organisation such as $H B A N K$. Our innovation operates in a multidisciplinary and matrix reporting environment. Consensus takes time to achieve when all functions are trying to avoid risk-taking. Therefore, leadership commitment is important to ensure collaboration in the organisation. Effective allocation of resources and communication with legal and regulators are critical to innovation diffusion success," said the bank manager.

The global team is located in the home country and has limited knowledge of the domestic market and policy framework. The local team needs to justify the innovation or modification to the global team. After the global team agrees the development priority, budget, timeline and supporting resources, the local team co-designs and cotests the new product with the global team. The whole process is conducted in different time zones, cultures and languages. However, a multidisciplinary approach does 
encourage knowledge-sharing and absorption among the actors. "Involvement in the multidisciplinary product development team allows me to understand and leverage successful innovation practices and experiences in other markets. I learn from the global team about new product experience in other regions, and I discuss how these can be adapted to our local market. We have regular cross-functional innovation sharing sessions to learn what is happening in other regional banks," said the customer account manager.

H BANK tends to exploit new applications of current innovation rather than explore new concepts or technologies. This indicates that innovation learning and localisation are important in H BANK. The product manager said, "We are a conservative bank. Normally, we do not launch brand-new financial products. It is easier to add new features to the existing product groups and explain to the regulator that the new enhancements do not change the risk profile of the already approved one." To achieve innovation deployment across business functions and locations, it is necessary to implement a global business template, standardise business processes and streamline the IT platform for global application. Technology development activities are conducted in the software house in India. The underlying idea seems to be that centralised innovation development is likely to promote product consistency, risk management, generalisability and overall cost-saving.

The following diagram illustrates the actors and their activities at $\mathrm{H}$ BANK in relation to the financial innovation process.

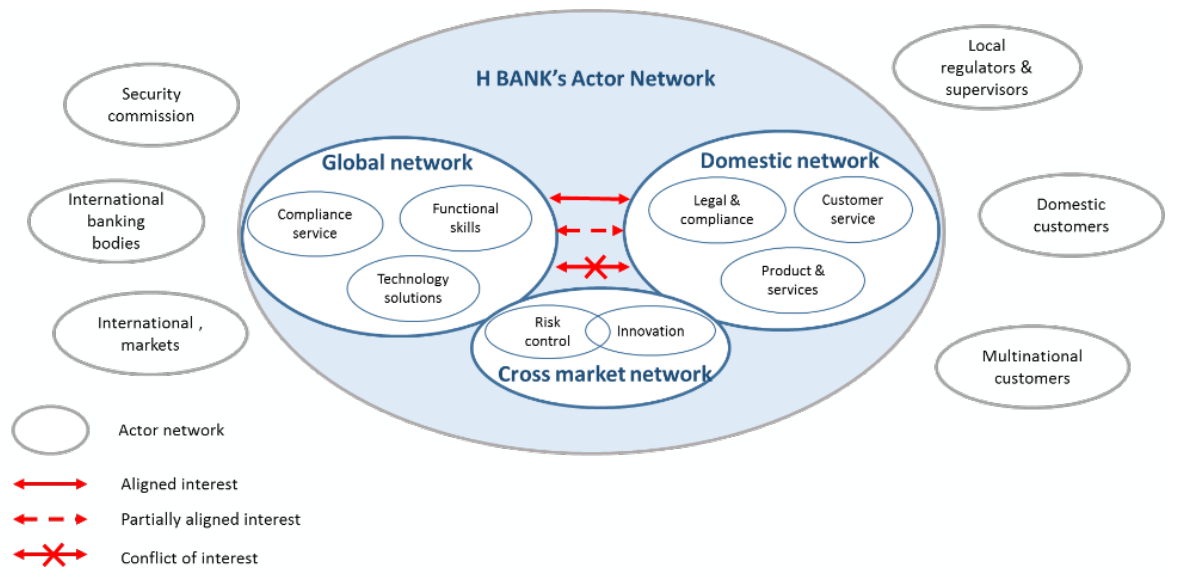

Fig. 2. The actor network model at H BANK

There are three main groups of actors in H BANK's actor network. The domestic actors are local functional teams that constantly interact with the in-country regulators, business partners and consumers. They sense changes and trends in domestic markets, understand needs and channel innovation ideas or requests to the global actors. The global actors are central policy-makers and headquarters teams that continue to liaise with international regulatory bodies, security commissions and worldwide markets. They are responsible for transforming regulatory requirements into company policy, developing in-house best practices and initiating strategic innovation. The cross-market actors are IT, legal, risk, finance and product specialists who are subject matter experts 
in their own fields. They help the domestic actors group to pre-screen innovation requests, give details of innovation specifications and support innovation development.

H BANK applies an actor network model in managing its innovation. According to Callon and Latour (1981), these networks can be potentially transient, existing in a constant making and re-making. The networks of relationships are not intrinsically coherent and may indeed contain conflicts (such as regulatory dialectics). In a networkbased environment, relationship supersedes formality, and therefore it is important to ensure actions conform to the interests of other clusters within the network. Involvement of different actors in the innovation process can greatly enhance innovation generalisability but also increases communication time and cost. To sum up, innovation development at $\mathrm{H}$ BANK shows a dialectic model in which changes are progressive outcomes of confrontation and conflict resolution among interested parties.

\subsection{Case Study 2: C BANK's two-layer model}

State-owned banks are large in terms of assets, branches, employees and customers., The Chinese government continues to have a strong influence over the lending practices and administration of state-owned banks, despite their being partially privatised. The board of directors and the senior bank officers are typically appointed by the Communist Party, and usually come from central government or Party agencies or one of the state-owned banks. In addition, the promotion of senior officers largely depends on Party agencies' recommendations, which makes them more responsive to the wishes of the central government than to the interests of the shareholders. Very often, central government agencies put direct pressure on bank officials to provide loans and services to specific government projects or state-owned enterprise investments (Martin, 2012). With the government as their largest shareholder, China's state-owned banks enjoy massive state support, fast growth and protection from direct competition with foreign banks. Chinese banks enjoyed high revenue growth of $13.5 \%$ compared to the $5 \%$ of foreign banks in 2014.

State-owned banks generally perceive SMEs to be high-risk, low-return clients. In general, they prefer lending to large clients such as China's state-owned enterprises (SOEs) and big private corporations, to assure repayment of loans and good relationships with increasingly influential figures in China's political system (Ma \& Sun, 2009).

In recent years, state-owned banks have been facing more challenges than ever before:

- The Chinese economy is slowing down.

- The risk of economic periodic fluctuation is causing assets to undergo significant value adjustment.

- Interest liberalisation and the rise of Internet finance are squeezing profits.

- Foreign banks, privately owned banks and Internet finance firms are challenging their monopoly and power.

- Their state-like remuneration and career path make it more difficult for them to attract and retain talent.

- Their innovation capability and risk management mechanisms generally lag behind the market. 
"In China, most of the financial market products introduced over the years came from Western banks. I have worked in the industry for 28 years, at different banks in China, and although I say this in connection to C BANK, I think that all of the Chinese commercial banks have the same problem with innovation. Our clients also have more and more sophisticated financial service needs, not just limited to loans and deposits," said the division manager.

Most of C BANK's innovations are found to support government policy implementation, such as financial inclusion, farmer financing, sustainable development and corporate social responsibility. As one of the largest employers in the country, $\mathrm{C}$ BANK assumes a social responsibility to ensure a healthy level of employment and financial and economic stability in the country. It continues to expand financing according to policy direction, and is gradually developing its innovation capability to meet the requirements of the new business landscape. As a result, business strategy and performance may not be fully oriented to profit maximisation.

However, in recent years the government has begun to reform the banking system, moving toward a market-oriented economy. More financial innovation from local banks has emerged as a result of deregulation. For example, in December 2006, CBRC requested that local banks, especially state-owned banks, increase their share of noninterest income (which generally accounts for over $50 \%$ of total revenue in major international banks, but less than $30 \%$ in Chinese commercial banks) through innovation.

Foreign strategic investors have played an important role in C BANK's innovation capability by transferring knowledge of advanced banking practice, product design and risk governance to their Chinese counterparts. Collaboration between C BANK and its strategic foreign investors in quality systems, risk governance, IT platforms, international banking and data analytics has strengthened C BANK's innovation capabilities. "Through strategic programme partnership, we have been exposed to international banking practices and advanced financial instruments $R \& D$. We consider that implementing modern corporate governance practices is central to achieving our objective of becoming an internationally competitive and modern commercial bank. We recognise that innovation is the way forward for the industry, and it plays a key part in the growth journey of the bank. We are committed to continuing to enhance customer experience and bring added value to our clients through financial technology adoption," said the bank manager.

Instead of engaging in costly radical innovation, C BANK prefers to copy mature foreign products or enhance existing products to make them more consumer-oriented and localised. C BANK, however, also engages in brand-new product development when it needs to support government policy implementation. As the product manager said, "When we are a follower, we focus on enhancing the product features of other banks' innovation. When we are an innovator, we have to carefully plan and manage the innovation product lifecycle. The design, flexibility and sustainability of an innovation can create market differentiation and help enhance the bank's innovation capability."

Based on the empirical study, organisational trajectory, bureaucracy and a hierarchical, risk-adverse culture are found to be restricting C BANK from radical innovation. Employment in state-owned banks is considered safe and secure, and therefore no one 
wants to risk their career path for risky innovation. The incentive system in state-owned banks is loyalty-based and does not encourage creativity. Everyone tends to play safe and apply the principles of 'more control is better' and 'sign-off practice' for collective responsibility in the innovation process. Most state-owned banks generally lack sales support, product packaging, customer care and internal coordination across branches and departments in innovation diffusion, compared to international banks. "Stateowned banks should continue to enhance their IT capability and market service mindset. IT is important as an innovation designer and executor," said the customer care manager. As a state-owned bank, C BANK is subject to government control over its operations and leadership appointments. As a listed entity, it has financial fiduciary responsibility to shareholders and customers. C BANK needs to balance these agency issues and stakeholder responsibilities in its operation and innovation model.

The following diagram illustrates the different actors and their activities at $\mathrm{C}$ BANK in relation to the financial innovation process.

Upper Layer
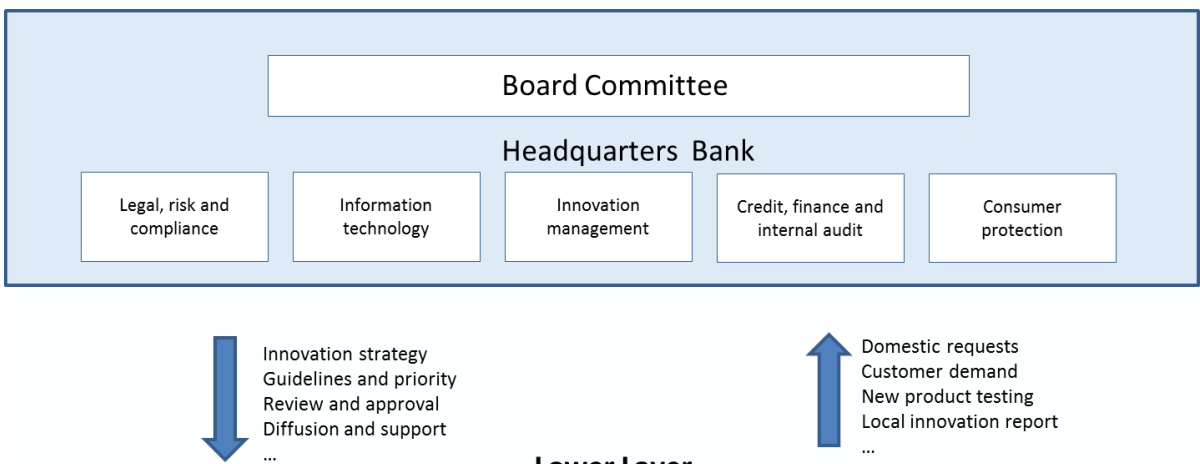

Lower Layer

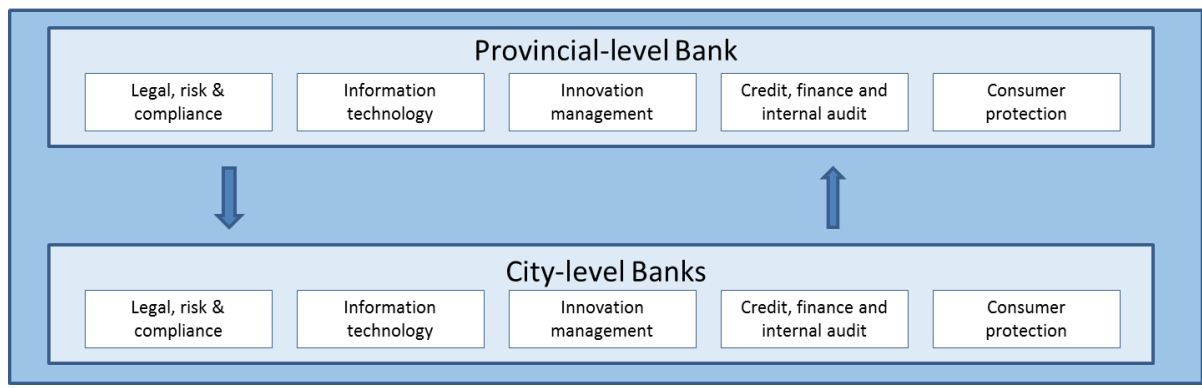

Fig. 3. The two-layer model at C BANK

The upper layer represents the board committees and the product R\&D team at headquarters (HQ) that are responsible for interpreting government policy, establishing an innovation roadmap, overseeing innovation development and allocating innovation resources. The lower layer represents provincial banks and team members who participate in the innovation process on a selective basis and are responsible for providing market insights and testing the product before launching. Their involvement helps validate the product conceptual design in the early stage of development and allows the R\&D team to hear the voice of customers. 
Strategic and nationwide innovations (related to regulatory changes and international banking) are initiated and constructed at HQ. Provincial and municipal banks may also engage in innovation activities based on guidelines from HQ. These innovations are generally developed to support the municipal government's domestic economy and financial policy. They are, however, confined by the existing product category and approval from HQ.

There are two types of innovation communication at $\mathrm{C}$ BANK. In top-down communication flow, long-term innovation goals, intentions and roadmaps are translated into operation goals and communicated down to drive collective actions with a minimum of discretion (Burgelman \& Grove, 2007). Messages from the top provide broad direction. Lower-layer staff autonomously undertake specific actions that serve domestic needs. Slack and Lewis (2011) describe this process as "objectives and actions, at least partly by the knowledge it (organisation) gains from its day-to-day activities" (p.13). Bottom-up communication is upward reporting and innovation ideation: collecting information on market trends and customer needs, conducting business case analysis and providing innovation suggestion to upper management. Additional control features are suggested and added to the innovation by upper management, to mitigate risk. The resulting innovation outcomes can be significantly different from the initial proposals, after multiple rounds of managerial review and functional modification. The new products sometimes can be too conservative and therefore lack creativity and commercial value. "Perhaps we should look into some mechanism, such as new product insurance or a financial laboratory test, to protect the bank's risk (consequential loss) and yet encourage creativity in the innovation process," said the product manager.

The innovation process at $\mathrm{C}$ BANK is characterised by pro-government policies, centralised control and a top-down function-based governance structure. This innovation model enhances R\&D efficiency, but also leads to increased diffusion costs, due to a lack of cross-division coordination. The layered innovation model is suitable for C BANK: the innovation process is rational, well documented and collectively accounted for. Innovation at $\mathrm{C}$ BANK shows a lifecycle model that prescribes a series of planned activities grouped into stages or phases. People at C BANK proactively adapt to their environments and make use of rules to accomplish their goals.

\subsection{Case Study 3: P BANK's iterative loop model}

A joint stock commercial bank is owned by several large investors. These investors can be local private companies, foreign banks or companies, local government (or its agencies) or individual investors. A joint stock equity structure means that several key investors must collaborate to formulate the bank's market strategy, development plan, product profile, customer policies and innovation roadmap. It is similar to the idea of a joint venture, where two or more key strategic partners collaborate to create a new company, product or service, or to enter a new market.

By opening up ownership and control to outsiders, a commercial bank can leverage the know-how of its strategic investors to develop new market strengths and innovation capability. Joint stock banks are considered more open and innovative than state-owned or foreign banks. This is because of their flat organisational structure and lean operation, which can promote innovation and profit optimisation. Fu and Heffernan 
(2007) assess the impact of different ownership types and bank performance on Xefficiency (the ability of a firm to get maximum output from its inputs) in 14 key banks (1985-2002), and find that on average joint stock banks are more X-efficient than stateowned banks. Similarly, Yao et al (2007) use panel data on 22 state-owned and nonstate banks in China for the period 1995-2001. They find that two factors have a significant impact on the level of efficiency: ownership characteristics and equity/asset ratio. On average, non-state banks outperform state-owned banks by $8-18 \%$ in terms of profitability.

However, joint stock banks face challenges in loan and resource allocation (Martin, 2012):

- Continued presence of local government or its agencies, with direct and indirect means to influence the operation of the banks.

- Pressure from private stockholders to provide preferential treatment to their companies, their families and/or their friends.

Two types of innovation are found at P BANK - group-driven and local-driven. The former refers to breakthrough, strategic and cross-functional innovations which are centrally managed and coordinated by the group. A centralised innovation process allows ideas to be prioritised, resources to be best allocated and new technologies to be invested in long-term evolution. The latter refers to incremental, operational and single function innovations which are domestically developed and deployed to meet local or specific market needs. A decentralised innovation process allows speed-to-market and local partnership for quick wins and market penetration. To encourage grounded innovations, the group also organises an annual innovation competition to select and promote top innovations to roll out to other markets or business units. The core idea is to avoid repeated investment and fully exploit existing innovations for new markets, new customers and new uses.

As a financial conglomerate, a rich product portfolio is fundamental to P BANK's diversified customers and markets. Including related business entities in the value chain (banking, insurance, credit guarantee, investment, security and financial asset exchange) of the innovation planning process helps align innovation priorities, avoid competitive or repetitive development, and ensure a structured product catalogue to unearth business synergy from a shared customer portfolio and IT platform. The bank manager said, "P BANK's innovation is to fulfil the comprehensive business needs of its large customer base across different service lines. The integrated or bundled financial products help us to improve our customer loyalty and customer lifetime value, which is a measurement of the total expected revenue from a customer over their entire relationship with our firm. For example, trade finance can bring terminal market customers to the bank. Credit cards bring insurance customers to the banking business. Micro-financing can integrate trade finance and credit card customers together in a single platform."

Financial conglomeration also poses new challenges to the Chinese financial supervisory framework, which is segregated by financial industry type. For example, the China Banking Regulatory Commission (CBRC), the China Insurance Regulatory Commission (CIRC) and the China Securities Regulatory Body (CSRC) separately supervise banks, insurance companies and securities firms respectively. The 
development of mega-banks is a new trend in China, with traditional commercial banks beginning to consolidate other non-bank financial offerings or venture into new areas of business such as e-commerce. Supervisory functions need to evolve to address increasingly open and IT-oriented banking operations.

Instead of the conventional sequential model, for speed-to-market P BANK adopts a concurrent engineering (Nonaka, 1990) approach to innovation. The innovation phases loosely connect, overlap, expand and contract with some elasticity in member or functional diversity. In a parallel processing set-up, internal conflicts may occur, which trigger innovation objectives and specifications to revisit and redefine regularly. Group identity is developed through knowledge sharing and constant interaction. When knowledge is shared within a cooperative and tight-knit relationship, scepticism is normally perceived as less hostile and good ideas are generally well received. This reduces barriers to innovation and creative ideas. The following diagram illustrates innovation activities at $\mathrm{P}$ BANK.

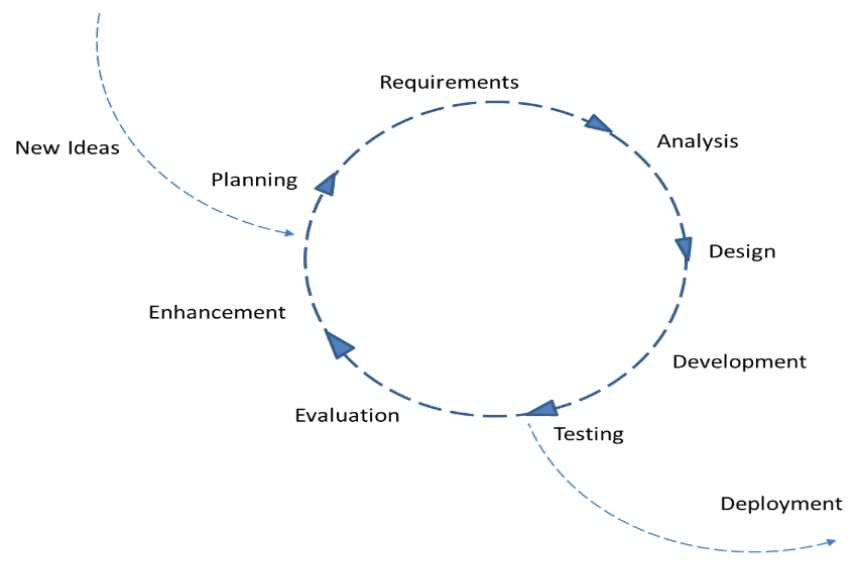

Fig. 4. Iterative loop model at $\mathrm{P} B \mathrm{BANK}$

Business groups at P BANK initiate an innovation proposal by submitting a business case. The innovation process at P BANK begins with a new idea entering an iterative development loop. The loop comprises ideation, planning, requirements clarification, analysis and prioritisation, conceptual design, product development and testing activities. After successful testing, the innovation is deployed in the market. The product team continues to observe and evaluate product performance in the market. Some minor adjustments may be needed to generalise the product, in order to meet larger market needs. Over time, the product team accumulates feedback and enhancement requirements from front-line staff and key customers. Once significant enhancement needs have been justified, the product goes into a second loop. This loop entails multidisciplinary team involvement, multidimensional coordination and communication, elastic and cooperative development, continued product perfection and risk governance.

Speed to market is prioritised over product functionality in the initial launch. The product development manager said, "P BANK continuously learns from and with customers, moving away from a product focus to a total concept focus - one customer, one account, multiple products and one-stop services - where activities are conducted 
in parallel by cross-functional teams." This innovation model enables P BANK to rapidly construct a prototype within a short timeframe. It helps the product team to evaluate product design, user experience and market acceptance at an early stage. Each iterative development loop adds new features to the product and improves its overall quality and performance. However, iterative development may increase communication time and cost. The concurrent working team must have tacit knowledge of the other functions before it can contribute to the development. There is a great deal of training and coordination before development speed can pick up.

The innovation process at P BANK features multiple business groups, elastic phases, value chains and iterative loop-based innovations. The advantages are rapid development time, leverage of existing competencies and a flexible workforce. However, there are challenges in the informal coordination between phases, execution risks if formal planning is superior to informal negotiation or adjustment, and political risk if the informal process kills the formal process. Management needs to exercise extra care to allow increased mutual adjustments, additional explaining and redoing, the sourcing of suppliers and clients, and the development and stabilisation of relations (Romelaer, 2015).

The iterative loop model is suitable for P BANK, as the innovation decision is coordinated, interactive and fast-tracked to meet market needs. Innovation development at P BANK shows an evolutionary model in which change is a repetitive sequence of variation, selection and retention events among entities in the population. "A greater number of diverse variations are more likely to produce innovations than a process that generates a small number of homogeneous variations" (Van de Ven and Sun, 2011).

\section{Discussion}

Most researchers agree that the innovation process does not "unfold in a simple linear sequence of stages and substages. Instead, it proliferates into complex bundles of innovation ideas and divergent paths of activities by different organisational units" (Van de Ven, 1995). Also, as Poole (2004) puts it, “... managers and change agents should realise how difficult change and innovation are to script and manage, as these processes constantly move in unexpected directions and are driven by dynamics that are either too powerful to control or too subtle to understand." Based on the empirical study, the innovation process adopted by Chinese banks shows a variety of models and interesting themes.

Table 3. Cross-case analysis: commonalities and differences

\begin{tabular}{lll}
\hline Comparison & Commonalities & Differences \\
\hline & Multidisciplinary & H BANK: International connectivity \\
Innovation approach & C BANK: Government policy \\
& $\begin{array}{l}\text { team using a project } \\
\text { approach }\end{array}$ & implementation \\
& P BANK: Business and client \\
& synergies \\
\hline
\end{tabular}




\begin{tabular}{lll}
\hline Comparison & Commonalities & Differences \\
\hline & $\begin{array}{l}\text { Generic process } \\
\text { consists of ideation, }\end{array}$ & H BANK: Globally consistent \\
conceptualisation, & C BANK: Top-down process \\
Innovation process & $\begin{array}{l}\text { evaluation, } \\
\text { development, testing } \\
\text { and diffusion }\end{array}$ & P BANK: Concurrent and integrative \\
& process \\
\hline
\end{tabular}

Based on the empirical analyses, Chinese banks use a multidisciplinary project team to develop financial innovations. The project manager and core team members are usually full-time staff from the function(s) responsible for leading the innovation process. Representatives and subject-matter experts from other supporting functions are involved as needed. In the innovation process, H BANK emphasises the ability to gain adequate market insights, identify key customer segments and develop customercentric solutions. To leverage global innovation competencies, a consistent innovation approach with minor adaptations for local regulatory compliance is applied at H BANK. C BANK focuses on comprehensive requirements collection, alignment with government policy and the bank's market proposition. For C BANK, it is important to support government policy implementation and fulfil its social responsibilities as a state-owned bank. P BANK prioritises speed-to-market and an integrated solution approach for its insurance, banking and asset management businesses. The integrated approach helps P BANK to develop innovative solutions that can maximise its business and client synergies in the value chain.

Based on the above findings, it seems that innovation approach is largely influenced by a bank's ownership, organisational culture and operation priorities. However, a multidisciplinary project team and organisational complexity also lead to inefficiencies such as inter-team conflict of interests, excessive communication to align objectives and tasks, overlapping duties and unclear responsibilities, and complexity in managing relationships and coordinating work. "Sometimes we spend too much time talking, instead of getting the work done," said the product manager. This study finds that functional diversity facilitates a more open innovation process with integration of knowledge from different functional disciplines, whereas functional similarity facilitates an in-depth innovation process where competence in a deep sense within a single or limited discipline enhances knowledge breakthrough.

Compared to $\mathrm{P}$ BANK, C BANK and H BANK are more risk-averse and conservative when dealing with innovation. Mangers in $\mathrm{H}$ BANK and $\mathrm{C}$ BANK display riskavoiding behaviour, with risk-taking considered unwise. These managers avoid taking risks, in order to protect their jobs. Bureaucracy and a hierarchical decision-making process result in managers being afraid to make mistakes that may lead to political scapegoating. They err on the side of caution, being more stringent and adding extra scrutiny measures to the innovation process. As a result, the approval process becomes more complicated and lengthy. The additional control requirements lead to the innovation losing some of the flexibility and user-friendliness of the original proposal. Some of these controls are not necessary to protect financial consumers.

All three processes analysed above have common features encountered in any financial 
innovation process: ideation, conceptualisation, evaluation, development, testing and diffusion. What is new here is that we see that in the same industry, here banking, the processes have original features that seem to be related to the property regime and organisation of each bank. For example, H BANK establishes an innovation network with multiple levels, and different clusters come together to act as a whole. H BANK leverages its international connectivity and global competency in innovation learning and deployment. Actions taken by domestic actors include implementing consistent business models, re-engineering global functions and processes, and streamlining the IT platform for effective diffusion in the local market. C BANK, on the other hand, has a bureaucratic and hierarchical organisational structure that supports a rational decision-making process. Pro-government policy, centralised, top-down control and conservatism are dominant and embedded in the organisational culture of state-owned enterprises like C BANK. To enable a top-down innovation process, it is important to develop an innovation strategy and roadmap, policy and procedures and broadly communicate them to the entire bank. What is interesting at P BANK is an integrated business model that emphasises a total business concept for customers, services, distribution and product integration. Innovation at P BANK entails cross-disciplinary action and high levels of integration at both intra- and inter-firm level, through open innovation with external partners, alliances and vendors. The overall objective is to build an integrated finance business ecosystem by leveraging P BANK's large customer base in the insurance business.

Therefore, we can say that innovation is a dynamic system that responds to severe market challenges and regulatory constraints or pressure. Innovation is a continuous change management process which is often messy and chaotic, striving to succeed amidst the complex silos in financial institutions. A successful financial innovation process encompasses myriad strategic and operational changes, involving modifications to processes, technologies, workflows, distribution channels and service deliveries. For example, financial innovations largely depend on ICT for development, discourse and delivery. Product concepts that seem promising but cannot be developed without major changes in information systems become an innovation constraint. For example, C BANK's legacy IT system constrained its innovation capability. It failed to meet the business needs of the new Internet finance regime. In 2015, C BANK did a major upgrade of its banking system to provide mobile technology-enabled e-banking and self-service offerings.

The case studies find that there is no one-size-fits-all innovation model. The innovation process is specific to business strategy and organisational trajectory. Therefore, firms need to diligently select and adopt an innovation process that matches their operating environment, innovation maturity, organisational structure and behaviour. As our three banks have different ownership regimes, we could at this point be under the impression that ownership dictates the nature of the innovation process. However, things seem to be a bit more complicated. The bank ownership structure strongly influences innovation strategy, approach and process. An innovation strategy that has a strong relationship with the state can offer protection and influence competitive intensity. Finally, regulatory and economic conditions may also influence the incentives for innovation. Lack of patent protection has also resulted in banks not being motivated to invest in product innovation. Instead, process innovation can create a more sustainable 
comparative advantage for banks. The majority of financial innovation activities are conducted sequentially, though some activities can run in parallel.

\section{Managerial and policy implications}

Innovation is a coefficient result of exogenous and endogenous drivers. Exogenous drivers are government policy, market competition and customer demand that can be manipulated by the authorities through regulation. As a regulated industry, bank operations are sensitive to government policy direction and political agenda. Government can impose restructuring requirements to consolidate players or relax regulation to induce competition. Customer demand is affected by regulations on financial products, services and capital controls. Financial innovation is costly, timesensitive and risky. Regular regulatory dialogues, cross-checks and exchange of information help banks to pre-empt policy change and adjust their innovation strategy accordingly. Endogenous drivers include organisational set-up, performance pressure, organisational culture and incentive system. Organisational ownership, size, structure and diversification have significant effects on a bank's approach to innovation and related strategies. Innovation strategy is also affected by a bank's path dependency and leadership. Pro-innovation leadership, an open business culture and a performancebased incentive system help promote creativity and innovation. The above findings enrich the linear innovation model by connecting the innovation drivers to the innovation process through the selection of an appropriate innovation strategy.

Customer insight is found to be a key contributor to the financial success of an innovation. Besides policy changes, banks need to monitor fast-changing customer needs and build their ability to meet these increasingly sophisticated demands with more customer-centric products and easy-to-use features. Engaging customers in the innovation process is, however, easier said than done. Most banks still rely on an inhouse research department, external consultants and customer relationship managers to collect customer feedback for innovation. Some banks have started to collaborate with IT firms in big data analysis to improve their products' conceptual design and end-user usability for targeted customer groups or segments, based on identified customer attributes and transaction variables (van de Vrande et al, 2012).

Organisational trajectory is found to be a key constraint to financial innovation. High compliance costs, complex hierarchies, legacy systems and IT bottlenecks also affect the scope and openness of innovation. The organisational structure and historical constraining issues, according to Vermeulen (2004), are organisational trajectories whereby individual actors have a certain amount of freedom to act, but not everything is possible due to the restrictions imposed by the history of the trajectory. Existing monopolies and competencies can hinder innovation due to path dependence and competency traps (March, 1991; Levinthal and March, 1993). Managers must proactively adapt to their environments and make use of rules to accomplish their goals. It is common in China to have trial procedures before a formal change is put in place. Managers collect operational data to improve and formalise the trial procedures. A more permanent solution or formal policy and procedure is then established, based on the trial run results and implementation feedback. 


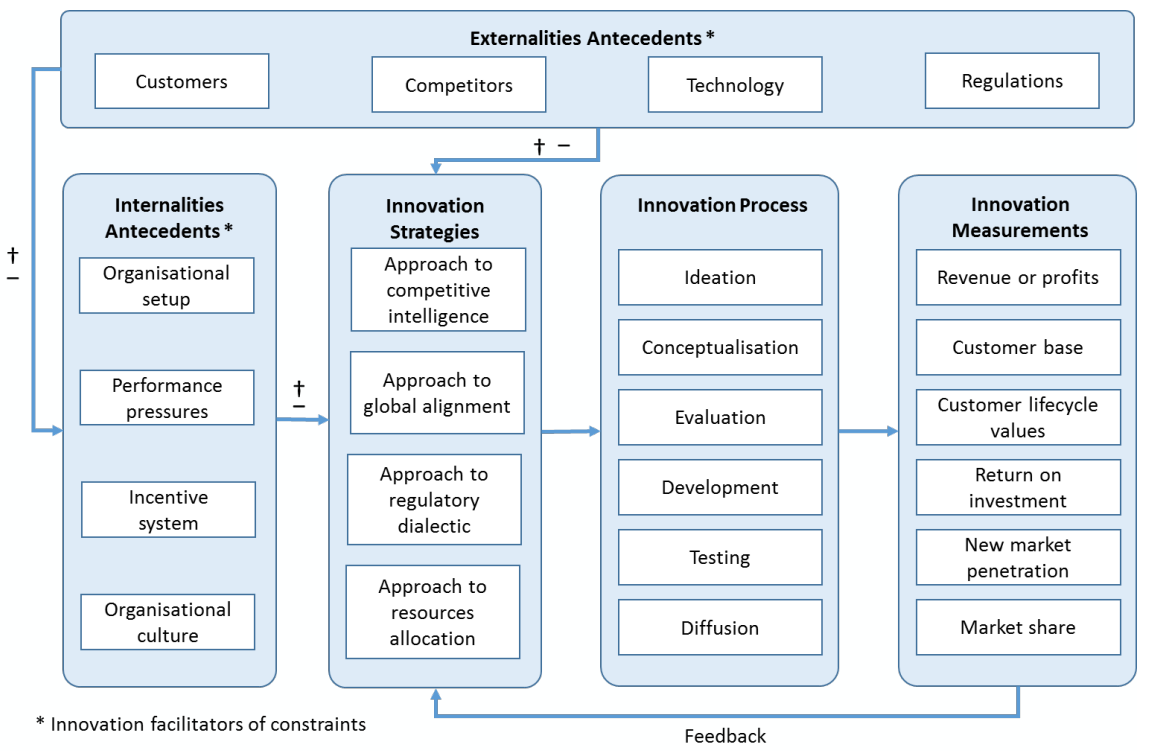

Fig. 5. An integrated approach to innovation in financial services

Applying an integrated framework can help managers to maintain a holistic view over the innovation process and outcome. The framework covers four dimensions: innovation antecedents, strategy, process and measurement. Innovation antecedents or drivers are further divided into two key types: externalities and internalities. The antecedents can have a positive or negative impact on a firm's innovation strategy, process and performance. Innovation professionals must conduct comprehensive environmental screening to identify the influential antecedents - antecedents that have a significant impact on the firm's innovation in terms of compliance, opportunity, resource allocation, market share, financial performance, customer segments and competitiveness advantages. Failure to identify and take proactive action to adjust the firm's innovation strategy may lead to innovation failure, regulatory punishment, negative financial impact and loss of market share. Besides observing and monitoring the trends and movements of the antecedents, innovation professionals can develop programmes to adjust the antecedents in order to build positive momentum or energy in the innovation process. For example, in P BANK, through adjusting the incentive system, establishing strategic alliances and investing in ICT technology, new inventions created new opportunities for the firm which would not have existed with a 'do-nothing' strategy.

Innovation strategy is closely linked to antecedents and a firm's business strategy. There are three key components of innovation strategy: alignment with long-term business strategy, approach to regulatory dialectic and resource allocation policy. For example, H BANK adopts a 'trusted foreign friend' approach to financial innovation in China. This means the approach to regulation dialectic is to follow and support Chinese policy direction, which leads to a risk-adverse innovation strategy in China with an overall theme of engaging in regular dialogue with regulators, formal or informal, to make sense of the political direction. 
Innovation process management consists of ideation, conceptualisation, evaluation, development, testing and diffusion. The innovations can be new products, services, channels, processes, business models, etc. For different types of innovation, the focus of the innovation stages can be significantly different. For example, product and service innovations involve all the stages and have multi-disciplinary participants from different functions or hierarchical levels. Channel innovation, on the other hand, is likely to focus on diffusion and commercialisation. Business model innovation likely involves strategic partnerships, expansion into new business areas and a comprehensive business case review. To measure the success of innovation, banks apply a combination of measurements, which can be general or specific; financial or non-financial; quantitative or qualitative; short-term or long-term performance indicators. Revenue, profit margin, investment return, customer base increase, asset and liability balance, and customer lifecycle value are found to be the common key performance indicators in the financial industry in measuring innovation results.

Regulation is a mounting concern across many industries, particularly those directly affected by healthcare reform, financial legislation and environmental changes. The integrated approach to innovation helps practitioners in highly regulated and innovation-driven industries, such as financial services, healthcare, automotive, pharmaceutical and life science, to effectively manage regulatory risk when engaging in innovation activities, in order to ensure both process and outcome compliance. This approach is also applicable to technology-driven industries where a firm's institutional arrangement and institutional environment are subject to rapid change and have strong influences over its innovation strategy, process and outcomes.

A key challenge for policy-makers is to strike the right balance between regulation and innovation - to regulate financial market operations without stifling innovation. The basic assumption is that innovators continuously take advantage of regulatory loopholes to innovate, whereas regulators close the loopholes by tightening the regulations. Based on Kane's (1977) regulatory dialectic, banks always search for new modalities to circumvent the regulations that affect their profitability. The conflict is intensified by the rapid development of the Internet finance economy in China, which includes the rise of online payment platforms, P2P lending platforms, online distribution of financial products and crowdfunding.

In this regard, Chinese regulatory bodies should consider the following measures in addressing the regulation dialectic:

1. Online and offline integrated supervision. Using cloud computing, big data and advanced data analytics techniques, regulators can obtain real-time innovation and compliance data from banks' systems. Advanced risk modelling can be developed to analyse and monitor banks' online and offline risks. Small and Micro Financial Services Group (2014) envisages that the regulatory framework will eventually transform into one that is real-time and interactive, similar to the financial big data flowing within, and that focuses on the lifecycle of data, namely its generation, transmission, usage, etc.

2. Principle-based, rather than rule-based, approach to supervision. Chinese financial laws and regulations are complex and issued by different regulatory bodies. A principle-based approach is more flexible, to accommodate the continuing evolution of financial instruments and risk. Limiting regulations to 
core principles and producing strong guidance rather than complex rules would be a significant step in this direction.

3. Single regulator across banking operation jurisdictions. The Chinese financial system is divided and regulated by multiple jurisdiction bodies. There are duplicated, conflicting or vague requirements from different regulators. More importantly, unclear responsibilities also result in unsupervised areas of bank operations. Chinese regulators should adopt a lead supervision model whereby a single regulator, usually the regulator responsible for a bank's core business activity, is responsible for the overall supervision of a bank. This should enhance cooperation and supervision quality across jurisdictions, with overall oversight being the responsibility of the lead supervisor.

4. Prudential and conduct supervision integration. The implementation of holistic business conduct supervision and consumer finance protection is relatively new for Chinese policy-makers. Advanced countries tend to integrate to a greater degree their financial sector supervisory structures. Improvements in overall public governance would also help drive Chinese regulators to adopt more integrated supervisory arrangements.

5. Useful disclosure instead of over-disclosure. Transparency is better achieved by the clear presentation of important information than by large amounts of raw data. Providing data without insight is potentially dangerous and could undermine the safety and soundness of individual banks and the industry as a whole in a volatile market. Regulators should encourage banks to provide the right, interpreted information to the public, instead of supplying excessive information.

\section{$7 \quad$ Limitation and future research}

The case studies focus on traditional commercial banking in China; therefore, the generalisability of the findings for other financial service sectors (such as Internet banking, trusts, asset management and securities) and other regulatory environments is limited. Also, a sufficient number of cases has to be evaluated in terms of the research questions and with regard to existing knowledge. With fewer than four cases, it is often difficult to generate a theory of much complexity, and the empirical grounding is likely to be unconvincing unless the case has several mini-cases within it. Also, data collection was principally based on interviewees, although triangulation was undertaken wherever possible by taping interviews, using two complementary methods for data collection, consulting internal documents and secondary data, and by observing the innovation in practice.

The author suggests that future research could enlarge the unit sampling to include privately owned, rural cooperation and Internet banks in different regulatory environments or countries. New forms of financial services, including cryptocurrency, Internet cloud banking, peer-to-peer lending, third-party payment platforms, online financial markets and asset securitisation, should also be considered in future research. Finally, the unit of analysis should consider different forms of innovation in banking, and where possible the integrated approach to innovation should be tested and validated in further research using a quantitative study approach. 


\section{References}

Abernathy, W. J., \& Clark, K. B. (1985). Innovation: mapping the winds of creative destruction. Research Policy, 14, 3-22.

Acs Z. J., Anselin L., Varga A. (2002). Patents and innovation counts as measures of regional production of new knowledge. Research Policy, 31(7), 1069-1085.

Adams, R. Bessart, J. \& Phelps R. (2006). Innovation management measurement: a review. International Journal of Management Reviews, 8(1), 21-47.

Aiken M., \& Hage, J. (1971). The organic organization and innovation. Sociology, 5(1), 63-82.

Akamavi, R. K. (2005). A research agenda for investigation of product innovation in the financial services sector. Journal of Services Marketing, 19(6), 359-378.

Alam, I. (2002). An exploratory investigation of user involvement in new service development. Journal of the Academy of Marketing Science, 30(3), 250-261.

Argyris, C., \& Schon, D. (1978). Organisational learning: a theory of action perspective. Reading, Mass: Addison Wesley.

Athanassopoulou, P., \& Johne, A. (2002). Effective communication with lead customers in developing new banking products. International Journal of Bank Marketing, 22(2), 100-125.

Atherton, A., \& Hannon, P. (2000). Innovation processes and the small business: a conceptual analysis. International Journal of Business Performance Management, 2(4): 276-292.

Barnett, H.G. (1953). Innovation: The Basis of Cultural Change. New York: McGraw Hill.

Batiz-Lazo, B., \& Woldesenbet, K. (2006). The dynamics of product and process innovation in UK banking. International Journal of Financial Services Management, 1(4), 400-421.

Beccalli, E. (2007). Does IT investment improve bank performance, evidence from Europe. Journal of Banking \& Finance, 31, 2205-2230.

Beine, M. A. R., Cosma, A., \& Vermeulen, R. (2010). The dark side of global integration: increasing tail dependence. Journal of Banking \& Finance, 34(1), 184-192.

Berger, A.N., \& Udell, F.G.F (2002). Small business credit availability and relationship lending: the importance of bank organizational structure. Economic Journal, 112(477), F32-F53.

Berger, A. N. (2003). The economic effects of technological progress: evidence of banking industry. Journal of Money, Credit and Banking, 35(2), 141-176.

Blazevica V., \& Lievensb, A. (2004). Learning during the new financial service innovation process: antecedents and performance effects. Journal of Business Research, 57, 374-391.

Bradley L., \& Stewart K. (2003a). A Delphi study of Internet banking. Marketing Intelligence and Planning, 21(5): 272-281. 
Bradley L., \& Stewart K. (2003b). The diffusion of online banking. Journal of Marketing Management, 19(9/10), 1087-1109.

Burawoy, M. (1998). The extended case method. Sociological Theory, 16, 4-33. doi: $10.1111 / 0735-2751.00040$

Burgelman, R.A., \& Grove, A.W. (2007). Let chaos reign, then rein in chaos repeatedly: managing strategic dynamics for corporate longevity. Strategic Management Journal, 28, 965-979.

Callon, M., \& Latour, B. (1981). Unscrewing the big leviathan, or how do actors macrostructure reality?. In Cetina K. D. and Cicourel A. (Eds.), Advances in Social Theory and Methodology Toward an Integration of Micro and Macrosociologies. London: Routledge and Kegan Paul.

Calori, R. (2003). Essai: real time/real space research; connecting action and reflection in organization studies. Organization Studies, 7.

Chaston, I. (2011). Independent financial advisors: open innovation and business performance. The Service Industries Journal, 33(6), 636-651.

Chesbrough, H. (2006). Open innovation: a new paradigm for understanding industrial innovation. In Chesbrough, H., Vanhaverbeke W., \& West, J. (Eds.), Open Innovation: Researching a New Paradigm (1-12). Oxford: Oxford University Press.

Christensen, C.M., \& Raynor, M.E. (2003). The Innovator's Solution: Creating and Sustaining Successful Growth. Boston: Harvard Business School Press.

Cooper, R. G. (1998). Product Leadership: Creating and Launching Superior New Products. Reading, MA: Perseus Books.

Costanzo L.A., \& Ashton J.K. (2006). Product innovation and consumer choice in the UK financial services industry. Journal of Financial Regulation and Compliance, 14(3), 285-303.

de Brentani, U. (2001). Innovative versus incremental new business services: different keys for achieving success. Journal of Product Innovation Management, 18(3), 169-187.

Drucker, P., (1985). The Discipline of Innovation. Harvard Business Review.

Easingwood, C.J. (1986). New product development for service companies. Journal of Product Innovation Management, 3(4), 264-275.

Eisenhardt, K.M. (1989). Building theories from case study research. Academy of Management Review, 14(4), 532-550.

Frame, W.S., \& White, L.J. (2004). Empirical studies of financial innovation: lots of talk, little action?. Journal of Economic Literature, 42(1), 116-144.

FSB (Financial Stability Board) (2011). Shadow banking: strengthening oversight and regulation. Recommendations of the Financial Stability Board (Basel: Bank for International Settlements).

Fu, X., \& Heffernan, S.A. Cost X-efficiency in China's banking sector. China Economic Review, 18, 35-53.

Gerstlberger, W., Kreuzkamp, M., \& da Mota Pedrosa, A. (2010). Innovation 
management in the German savings banks. Innovative Marketing, 6(3), 60-71.

Glaveli N., \& Kufidu S. (2005). The old and young and the restless: a comparative analysis of the impact of environmental change on training in four Greek banks. European Business Review, 17(5), 441-459.

Gurau, C. (2002). Online banking in transition economies: the implementation and development of online banking systems in Romania. International Journal of Bank Marketing, 20(6): 285-296.

Hamel, G. (2002). Leading the Revolution. Boston: Harvard Business School Press.

Jaramillo, H., Lugones, G., \& Salazar, M. (2000). Manual de Bogotá : normalización de indicadores de innovación tecnológica en América Latina y el Caribe. Bogotá, Colombia: Proyecto Financiado por la Organización de Estados.

Jawahitha S. Ab. Hamid, N.R., \& Ishak M.M., M. (2003). Internet banking: A comparative analysis of legal and regulatory framework in Malaysia. Arab Law Quarterly, 18(3/4), 291-308.

Johannessen, J.A. (2009). A systemic approach to innovation: the interactive innovation model. Kybernetes, 38(1/2), 158-176.Kane E.J. (1977). Good intentions and unintended evil: the case against selective credit allocation. Journal of Money, Credit and Banking, 9, 55-69.

Kim, W.C., \& Mauborgne, R. (2005). Blue Ocean Strategy: How to Create Uncontested Market Space and Make Competition Irrelevant. Harvard Business Press.

Kumar, P., \& Turnbull, S.M. (2006). Patenting and licensing of financial innovations. Working paper, July, CT Bauer College of Business, University of Houston.

Kutvonen, A. (2011). Strategic application of outbound open innovation. European Journal of Innovation Management, 14(4), 460-474.

Lee, J., Kao, H.-A., \& Yang, S. (2014). Service Innovation and Smart Analytics for Industry 4.0 and Big Data Environment. Procedia CIRP 16, 3-8

Lerner, J. (2006). The New Financial Thing: The Origins of Financial Innovations. Journal of Financial Economics, 79, 223--255

Lerner, J., \& Tufano P. (2011). The consequences of financial innovation: $a$ counterfactual research agenda. Working paper 16780, National Bureau of Economic Research.

Levinthal, D.A., \& March, J.G. (1993). The myopia of learning. Strategic Management, $J(14), 95-112$.

Lichtenthaler, U. (2007). The drivers of technology licensing: an industry comparison. California Management Review, 49(4), 67-89.

Lievens, A., \& Moenaert, R. (2000). Project team communication in financial service innovation. Journal of Management Studies, 37(5), 733-766.

Lievens, A., \& Moenaert, R.K. (2000a). Communication flows during financial service innovation. European Journal of Marketing, 24(9/10), 1078-1110.

Llewellyn, D. (1992). Financial innovation: a basic analysis. Financial Innovation, ed. Cavanna, H. London: Routledge. 
Luecke, R. (2003). Managing creativity and innovation. MA: Harvard School Press.

Ma, J.T., \& Sun, J. (2009). The research of promoting the Chinese banking industry core competitiveness under the financial globalization background. International Journal of Economics and Finance, 1(2).

March, J.G. (1991). Exploitation and exploration innovation in organizational learning. Organizational Science, 2(1), 71-87.

Marcus, A.A. (1981). Policy uncertainty and technological innovation. Academy of Management Review, 6(3), 443-448.

Martin, M.F. (2012). China's banking system: issues for Congress. CRS Report for Congress, February 20, 2012.

Martovoy, A., \& Dos Santos, J. (2012). Co-creation and co-profiting in financial services. International Journal of Entrepreneurship and Innovation Management, 16(1-2), 114-135.

Martovoy, A., \& Mention, A.L. (2016). Patterns of new service development processes in banking. International Journal of Bank Marketing, 34(1), 62-77.

Meyer, A.D., Goes, J.B., \& Brooks, G.R. (1993). Organizations reacting to hyperturbulence. In G. Huber \& Glick (Eds.), Organizational Change and Redesign, 66-111. New York: Oxford University Press.

Moore, G.A. (2005). Dealing with Darwin: How Great Companies Innovate at Every Phase of Their Evolution. New York: Penguin Group.

Muniesa, F., \& Lacoste, A. (2012). Responsible innovation in finance: a culture of testing, public deliberation and shared knowledge. Debating Innovation, 2(2), 3338 .

Nonaka, I. (1990). Redundant, overlapping organization: a Japanese approach to managing the innovation process. California Management Review. Spring, 2738.

OECD (2005). Oslo Manuals. Guidelines for Collecting and Interpreting Innovation Data, 3rd edition. Paris: OECD.

Oke, A., \& Goffin, K. (2001). Innovation management in the service sector. Management Focus (Summer issue). Cranfield School of Management.

O'Sullivan, D., \& Dooley, L. (2009). Applying Innovation. Sage Publications.

Patton, M.Q. (1990). Qualitative Evaluation and Research Methods (2nd ed.). Newbury Park, CA: Sage. (1st ed. 1980. Qualitative Evaluation Methods. Beverly Hills, CA: Sage).

Poole, M.S. (2004). Central Issues in the Study of Change and Innovation. In Poole, M.S., \& Van de Ven, A.H. (Eds.). Handbook of Organizational Change and Innovation, 3-31. New York: Oxford University Press.

Poole, M. S., Van de Ven, A. H., Dooley, K., \& Holmes, M. E. (2000). Organizational change and innovation processes: Theory and methods for research. New York: Oxford University Press.Prahalad, C.K., \& Krsihnan, M.S. (2008). The New Age of Innovation: Driving Cocreated Values Through Global Networks. McGrawHill.

Rasul, F. (2013). The Practice of Innovation - Seven Canadian Firms in Profile. 
Industry Canada.

Rigby, D., \& Zoo, C. (2002). Open-market innovation. Harvard Business Review, 80(10), 80-89.

Rogers, E.M. (2003). Diffusion of Innovation (5th ed.). New York: The Free Press.

Romelaer (2015). Innovation processes: has research developed a complete set of models for research and management purpose? Conference at the Department of Innovation Entrepreneurship and Strategy, School of Economics and Management, Tsinghua University, Beijing, March 18, 2015.

Rothwell, R. (1994). Towards the fifth-generation innovation process. International Marketing Review, 11(7). 7-31.

Schueffel, P. E., \& Vadana, I. I. (2015). Open innovation in the financial services sector - a global literature review. Journal of Innovation Management, 3(1), 25-48.

Schueffel, P. (2017). Taming the Beast : A Scientific Definition of Fintech. Journal of Innovation Management, 4(4) 32-54

Schumpeter, J.A. (1934). The Theory of Economic Development: An Inquiry into Profits, Capital, Credit, Interests and The Business Cycle. London: Oxford University Press.

Silber, W. (1983). The Process of Financial Innovation. American Economic Review Papers and Proceedings, 73, 89-95.

Slack, N., \& Lewis, M. (2011). Operations Strategy. 3rd ed. Harlow, England: Pearson Education Limited.

Small and Micro Financial Services Group (2014). Towards a big data-centered regulator framework: discussion on the characteristics of Internet finance ecosystem and potential impact on regulation. China Finance Review, 2.

Strambach, S. (2002). Change in the innovation process: new knowledge production and competitive cities - the case of Stuttgart. European Planning Studies, 10(2), 214-231.

Sumita, T. (2008). Intellectual asset-based management for innovation: lessons from experiences in Japan. Journal of Intellectual Capital, 9(2), 206-227.

Tiwari R., \& Herstatt, C. (2011). Frugal innovations for the "unserved" customer: an assessment of India's attractiveness as a lead market for cost-effective products. Working Paper No. 69, Institute for Technology and Innovation Management, Hamburg University of Technology.

Tushman, M.L., \& Romanelli, E. (1985). Organizational evolution: a metamorphosis model of convergence and reorientation. In Cummings, L.L., \& Staw, B.M. (Eds.), Research in Organizational Behavior, 171-222. Greenwich, CT: JAI Press.

Van de Ven, A., Angle, H.L., \& Poole, M.S. (2000). Research on the Management of Innovation: The Minnesota Studies. Oxford University Press.

Van de Ven, A.H., \& Poole, M.S. (1995). Explaining development and change in organizations. Academy of Management Review, 20, 510-540.

Van de Ven, A. H. and Poole, M. S. (2005). Alternative Approaches for Studying Organizational Change. Organization Studies 26(9): 1377-1404. SAGE Publications (London, Thousand Oaks, CA \& New Delhi) 
Van de Vrande, V., de Jong, P.J.J., Vanhaverbeke, W., \& de Rochemont, M. (2012). The case for big data in the financial services industry. White paper, IDC Financial Insights.

Vence, X., \& Trigo, A. (2009). Diversity of innovation patterns in services. Service Industries Journal, 29(12), 1635-1657.

Vermeulen., P. (2004). Managing product innovation in financial services firms. European Management Journal, 22(1), 43-50.

Wang, C., \& Kafouros, M. (2009). What factors determine innovation performance in emerging economies? Evidence from China. International Business Review, 6(6), 606-616.

Ward, J., \& Daniel, E. (2012). Benefits Management: How to Increase the Business Values of Your IT Projects (2nd ed.). John Wiley \& Sons.

Weick, K., \& Quinn, R.E. (1999). Organizational change and development. Annual Review of Psychology, 50, 361-386.

Yao, D., \& Zhuang, Y. (2004). Financial innovation microeconomics theory and empirical study. (in Chinese). Journal of Finance and Economics, 2004(9), 4755.

Yin, Robert K. (2009). Case Study Research: Design and Methods (4th ed.). Thousand Oaks: Sage Publications.

Zaltman, G., Duncan, R., \& Holbek, J. (1973). Innovations and Organizations. John Wiley \& Sons. 